\title{
Herpes encephalitis is a disease of middle aged and elderly people: polymerase chain reaction for detection of herpes simplex virus in the CSF of 516 patients with encephalitis
}

\author{
Marjaleena Koskiniemi, Heli Piiparinen, Laura Mannonen, Timo Rantalaiho, Antti Vaheri \\ and the Study Group
}

\begin{abstract}
Objective-To assess the diagnostic potential of the polymerase chain reaction (PCR) in herpes simplex virus (HSV) encephalitis.

Methods-Samples of CSF from 516 patients with encephalitis were studied for HSV-DNA by PCR.

Results-Samples taken one to 29 days from the onset of symptoms from 38 patients $(7 \cdot 4 \%)$ were positive, $32(6 \cdot 2 \%)$ for $\mathrm{HSV}-1$ and six $(1 \cdot 2 \%)$ for $\mathrm{HSV}-2$. At follow up, eight of 28 patients studied were still HSV-PCR positive. A diagnostic serum:CSF antibody ratio to $\mathrm{HSV}$ but not to other viruses was detected in 25 of the $38 \mathrm{HSV}-\mathrm{PCR}$ positive patients thus supporting the initial PCR findings. Patients positive by HSV-PCR were concentrated in the age group $\geqslant 40$ years, and especially in patients aged 60-64 years, of whom nine of $24(37 \cdot 5 \%)$ were positive. The HSV-PCR was negative in all other patients with encephalitis of known or unknown aetiology. This group included 34 patients with a diagnostic serum:CSF antibody ratio to other viruses. A dual infection, HSV and another microbe, was considered possible in seven patients.

Conclusions-The HSV-PCR is a rapid and useful diagnostic method during the early phase of encephalitis. It may be useful in monitoring the efficacy of treatment and allowing the recognition of new features in the appearance of herpes encephalitis. The HSV-PCR test and antibody determinations from serum and CSF are complementary methods, which should both be applied in pursuit of clinical laboratory diagnosis of these conditions.
\end{abstract}

(F Neurol Neurosurg Psychiatry 1996;60:174-178)

Virology, University of

Helsinki, Finland

M Koskiniemi

H Piiparinen

L Mannonen

T Rantalaiho

A Vaheri

Correspondence to:

Dr Marjaleena Koskiniemi,

Haartman Institute,

Department of Virology,

University of Helsinki,

Finland.

Received 31 July 1995

and in revised form

29 September 1995

Accepted 6 October 1995 Powell et $a l^{1}$ reported the rapid detection of HSV-DNA in CSF and Rowley et $a l^{2}$ reported the detection of HSV-DNA in four patients with HSVE. Samples of CSF from six patients with other CNS infections were negative for HSV. Since then the technique has been used in many laboratories interested in the diagnosis of HSVE. ${ }^{3-9}$ For example, in the study reported by Lakeman et al CSF-HSV was detected by PCR in 53 of 54 patients with HSVE established by brain biopsy, and in all 18 CSF samples obtained before brain biopsy. ${ }^{3}$ Additionally, HSV-PCR was positive in three of 47 patients negative on brain biopsy. These studies clearly show the diagnostic potential of the test. Brain biopsy is an invasive and demanding method for diagnosis. The HSV-PCR makes the diagnosis of HSVE easier and the clinical manifestations of HSVE will, without doubt, be recognised more thoroughly. We present our experience on 516 patients with encephalitis.

\section{Patients and methods}

We studied CSF samples from 516 patients with encephalitis who were cared for at central or university hospitals throughout Finland. Encephalitis was defined as acute onset of neurological symptoms reflecting focal or generalised involvement of brain tissue presenting as pareses, convulsions, linguistic or mental dysfunction, or lowered level of consciousness, with or without meningeal signs and symptoms. Most specimens were sent for laboratory diagnosis at the time of admission of the patient to hospital. The HSV-PCR test was performed if HSVE was suspected by the clinician, or antibodies to HSV were detected in the CSF, or a high antibody titre to HSV was found in serum. The age of the patients ranged from neonate to 86 years.

A PCR was performed on CSF immediately after receipt in the laboratory (one to three days after collection of the sample). Some samples were frozen and preserved at $-20^{\circ} \mathrm{C}$ until they were assayed. For HSV-PCR a 130 $\mu \mathrm{l} C S F$ sample was centrifuged at $4500 \mathrm{rpm}$ for five minutes at $4^{\circ} \mathrm{C} ; 100 \mu \mathrm{l}$ of the supernatant was treated with proteinase $K$ buffer and the DNA extracted using phenol/diethyl ether and ethanol precipitation. DNA was amplified in a $100 \mu \mathrm{l}$ reaction mixture containing $50 \mathrm{mM} \mathrm{KCl}, 10 \mathrm{mM}$ Tris $\mathrm{HCl}(\mathrm{pH} 8 \cdot 3)$, $1.5 \mathrm{mM} \mathrm{MgCl}_{2}, 0.01 \%$ (w/v) gelatin, $200 \mu \mathrm{M}$ each of the four deoxyribonucleoside triphosphates, $2.5 \mathrm{U}$ of AmpliTaq polymerase 
Figure 1 HSV-PCR positivity after the onset of the disease on admission to the hospital. Only the initial positive finding of the patient is included. The figures refer to the number of patients studied on each day. Eleven of 57 patients studied on the first day of symptoms were retested on days five to 14 and all were negative on that test except the positive patient who was still positive on day 9.

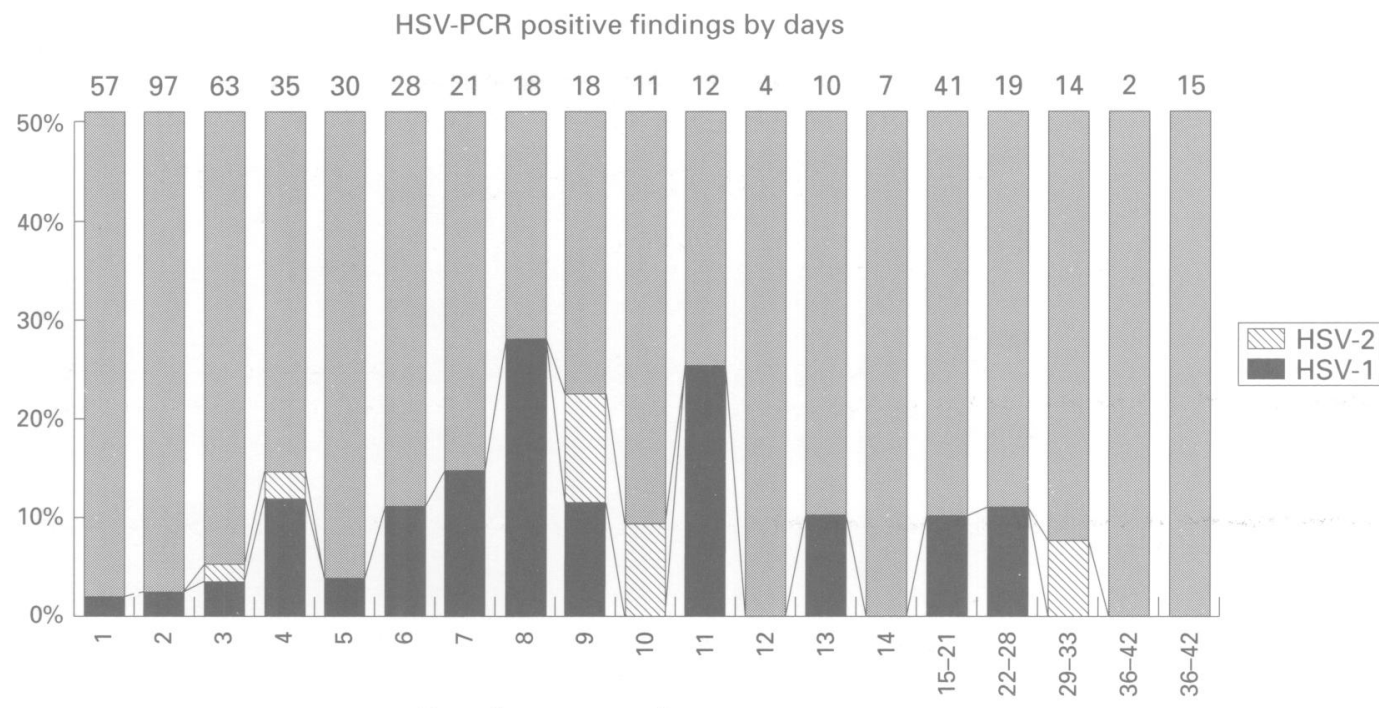

Days from onset of symptoms
(Perkin Elmer-Cetus, Norwalk, CT), and 100 pmol of the primers selected from the DNA polymerase gene for $\mathrm{HSV}-1$ and $\mathrm{HSV}-2$ - that is, 229 and 241 base pairs for HSV-1 and HSV-2. ${ }^{10}$ The amplified fragments reaction mixture was initially heated at $95^{\circ} \mathrm{C}$ for two minutes followed by amplification consisting of 40 cycles at $95^{\circ} \mathrm{C}$ for 25 seconds (denaturation), at $55^{\circ} \mathrm{C}$ for 30 seconds (annealing), and at $72^{\circ} \mathrm{C}$ for 30 seconds (extension, allowed to continue for 10 minutes after the last cycle) (Perkin Elmer-Cetus, GeneAmp PCR 9600 thermal cycler, Norwalk, CT). The amplified frequents PCR products were electrophoresed in $3.5 \%$ agarose containing $0.2 \mu \mathrm{g} / \mathrm{ml}$ ethidium bromide. PhiX174 RF DNA-Hae III digest (Biolabs, Beverly, MA) was used as a size marker. For definitive identification of the amplified HSV-DNA, samples with putative positive results were subjected to Southern blotting and hybridised with end labelled radioactive or digoxigenin oligonucleotide probes synthesised by an Applied Biosystems 381 A DNA synthesiser. Measures to avoid contamination were applied throughout the process. ${ }^{11}$

Antibodies against HSV-1, HSV-2, and varicella zoster virus were assayed using commercial enzyme immunoassay antigens (Virion ${ }^{\circledR}$, Würzburg, Germany), and recorded in enzyme immune units (the optical density of the specimen at a 1:200 dilution divided by the optical density of the positive control and then multiplied by $100^{12}$ ). The serum:CSF antibody ratio was calculated and considered diagnostic if $\leqslant 20$ with respect to the reciprocals of end point titres. ${ }^{13} \mathrm{HSV}$-specific IgM was determined with a commercial indirect IgM immunofluorescence kit (Gull Laboratories, Salt Lake City, UT). If positive, the test was repeated after IgG inactivation (Gullsorp absorption).

Antibody assays against adeno, influenza $A$ and $\mathrm{B}$, rota, Coxsackie B5, ECHO 22 (antigens grown and purified as described ${ }^{14}$ ), cytomegalo, parainfluenza 1 , and respiratory syncytial viruses $\left(\right.$ Virion ${ }^{\circledR}$ ) and Mycoplasma pneumoniae (gift from $M$ Kleemola, National
Public Health Institute, Helsinki) were measured in serum and CSF using enzyme immunoassay tests. For chlamydial diagnostic tests, a microimmunofluorescence method measuring IgG and IgM antibodies specific to Chlamydia trachomatis, Chlamydia pneumoniae, and Chlamydia psittaci was used. ${ }^{15}$ Antibodies to tick borne encephalitis and Puumala hantavirus (nephropathia epidemica) were measured if indicated, using an in house indirect immunofluorescence antibody assay. ${ }^{1617}$

Virus culture was attempted on $122 \mathrm{CSF}$ samples using four different cell lines; African GMK, Vero, human amniotic epithelial cells, and human embryonic skin fibroblasts.

\section{Results}

Of 516 patients, $38(7 \cdot 4 \%)$ were positive by the HSV-PCR test; $32(6 \cdot 2 \%)$ for HSV-1 and six $(1 \cdot 2 \%)$ for HSV-2. The test was positive in the first CSF specimen obtained, usually on admission to hospital; $82 \%$ of the samples were obtained within two weeks from the onset of symptoms. The HSV-PCR assay seemed to be of most value for confirming an aetiological diagnosis of HSVE when used during the first week after the onset of symptoms (fig 1). In one patient, HSV-PCR appeared positive (day 3) after an initial negative finding (day 2). Eight of the 28 patients, on whom follow up tests were performed, remained PCR positive six to 57 days after the first sample. In a 60 year old man with a chronic progressive disease the CSF sample was initially positive to HSV-1, but six months later to HSV-2, and in subsequent tests remained so despite prolonged treatment with acyclovir.

Patients positive for HSV-PCR were concentrated in the age group $\geqslant 40$ years, and in the 60 to 64 year age group HSV-DNA was found in the CSF in nine of 24 patients (fig 2). In the 1 to 4 year age group no positive findings appeared in any of the 50 children studied. Similarly, in the age group 10 to 24 years samples were negative in all 58 patients with encephalitis. In patients aged 40 to 59 years 


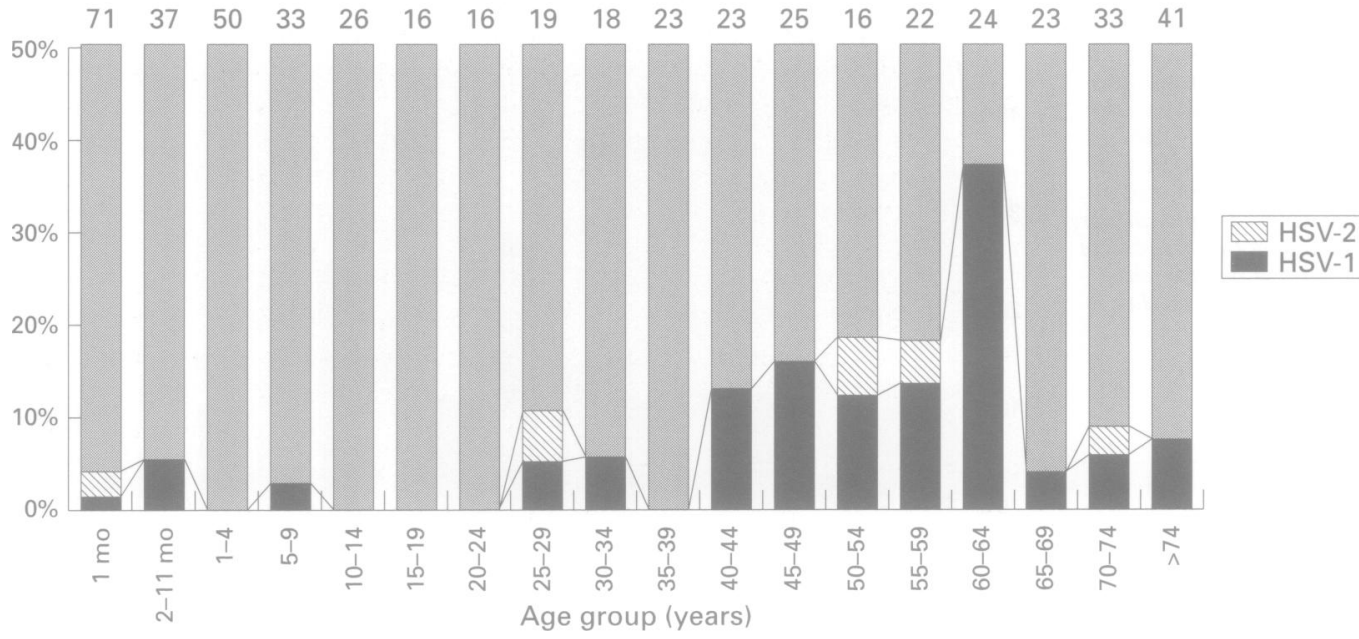

Figure 2 Distribution of HSV-PCR positive findings in different age groups. The figures refer to the number of patients studied in each age group.

Patients with diagnostic ratio of HSV-ABs in serum/CSF

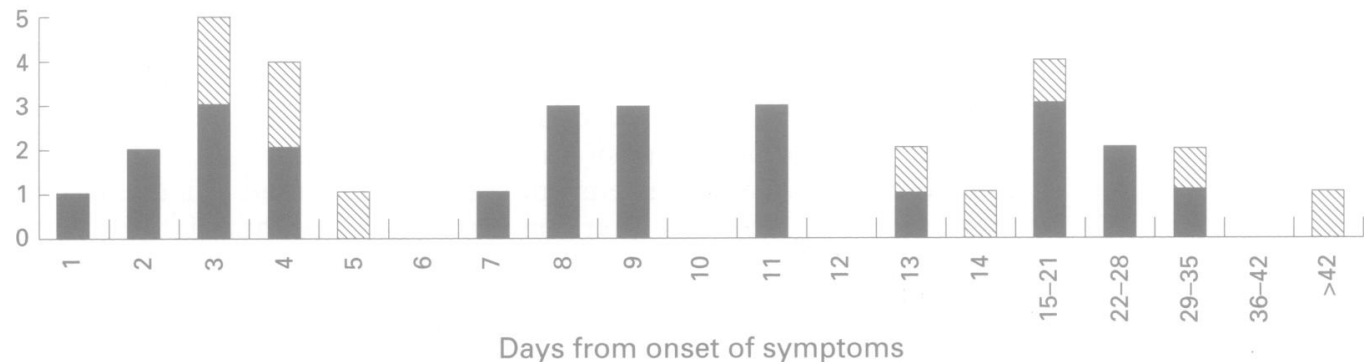

Figure 3 Distribution of HSV-PCR findings in those patients who afterwards developed a diagnostic serum:CSF antibody to $H S V$. The day refers to the day when HSV-PCR was performed.

PCR positivity ranged from $13 \%$ to $18 \%$ of patients with encephalitis studied. Findings of HSV-2 were distributed across the age range. The rate of PCR positivity did not show seasonal variation.

The HSV-PCR was negative in all other patients with encephalitis of known or unknown aetiology including 34 patients with a diagnostic serum:CSF (S/CSF) antibody ratio to some other microbe and 10 patients with a diagnostic S/CSF ratio to $\mathrm{HSV}$ (fig 3). In the HSV-PCR positive group a diagnostic $\mathrm{S} / \mathrm{CSF}$ antibody ratio to $\mathrm{HSV}$ was found in 25 of $38(66 \%)$, thus supporting the initial PCR result. A possible dual infection appeared in seven HSV-PCR positive patients (table).

HSV-PCR positive patients with a concomitant diagnostic finding of some other microbe

\begin{tabular}{lrll}
\hline Age (sex) & Date of HSV-PCR & Microbe & Finding \\
\hline $64(\mathrm{~F})$ & 9 & HSV-1, PHV & PHV IgM positive \\
$62(\mathrm{M})$ & 19 & HSV-1, VZV & VZV S:CSF ratio \\
$47(\mathrm{M})$ & 4 & HSV-1, CHL & CHL IgG and IgM positive \\
$64(\mathrm{M})$ & 6 & HSV-1, TBE & TBE IgM positive \\
$29(\mathrm{~F})$ & 10 & HSV-2, VZV & VZV S:CSF ratio \\
61 (M) & 8 & HSV-1, CHL & CHL IgG and IgM positive \\
NB (F) & 7 & HSV-1, HIV & HIV antibodiest \\
\hline
\end{tabular}

^Days from the onset of the diseases.

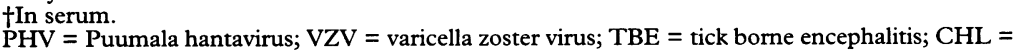
Chlamydia pneumoniae; $\mathrm{NB}=$ newborn.

\section{Discussion}

The PCR provides a highly sensitive method for the identification of viral invasion of the CNS at an early stage of infection. ${ }^{18}$ In the present study HSV-PCR seemed to be specific as indicated by the negative results obtained from many patients with encephalitis of various aetiologies and by the positive results which were confirmed by a concomitant or subsequent antibody response in $66 \%$ of cases. The number of non-responders, with no intrathecal antibody production, was similar to the numbers reported by Nahmias et al ${ }^{19}$ and Anderson et al. ${ }^{20}$ The use of HSV-PCR represents an improvement over viral culture and antigen detection from the CSF. ${ }^{2122}$ Diagnostic brain biopsy in CNS infections is considered appropriate in prolonged and complicated cases only. Nevertheless, detection of HSV from brain tissue biopsy or necropsy remains the reference method for confirmation of HSVE.

Our findings indicate failure of treatment to eradicate HSV-DNA in the CSF, an observation similar to that found in other studies..$^{823}$ In eight of 28 patients HSV-PCR was still positive six to 57 days after the first positive finding, despite treatment with acyclovir. It has been reported that the highest PCR signals are reached at days five to six of acyclovir treat- 
ment. ${ }^{24}$ In one of our patients, the initial HSV1 PCR positivity disappeared, and six months later PCR showed HSV-2 positivity which in subsequent CSF samples remained positive for months despite repeated courses of acyclovir, suggestive of therapeutic failure.

In this study it is apparent that HSVE seems to affect predominantly middle aged and elderly people. Positivity on PCR was recorded for $37.5 \%$ of patients aged 60 to 64 years with encephalitis. This may reflect the prevalence of the virus genome in the brains of older people. ${ }^{25}$ Among people aged $\geqslant 65$ years, however, HSV-PCR positivity remained $<10 \%$, although herpes encephalitis was often suspected. With increasing age, other aetiological agents, such as influenza viruses appear (M Färkkilä et al, unpublished observations).

Only a few PCR results on children after the newborn period have been published..$^{823}$ In our series no patients with HSVE were found in the adolescent groups. Among children, a few cases were identified. A negative HSVPCR result may reflect a low amount of virus in the CSF, the disease process may be deep within the brain, or the primers used may not have been suitable to detect the virus type or strain causing the infection. ${ }^{27} 28$ The overall HSV-DNA detection rate in our series was a little lower than in the study by Puchhammer et $a,^{24} 7 \cdot 4 \%$ v $8.9 \%$. However, in our study serological confirmation rate was higher $(66 \% v$ $39 \%)$.

In 10 patients with a diagnostic serum:CSF antibody ratio to HSV, PCR remained negative even though some samples were obtained during the first two weeks. The HSV antibody response was considered diagnostic because there was no evidence of intrathecal production of antibodies to other microbes in the CSF. It is apparent that detection of HSV specific DNA from the CSF may sometimes be problematic. ${ }^{22}$ A negative PCR result should always be critically assessed, repeated sampling may be worthwhile, and other laboratory diagnostic procedures should be performed. A nested PCR protocol may be more sensitive than a single PCR. In a clinical laboratory, however, the inherent risk of contamination of amplified products makes the use of nested PCR problematic. Enzyme linked immunosorbent assay based detection systems, using streptavidin-coated microplates, biotinlabelled probes, and luminometric reading with appropriate substrate, may enhance the sensitivity. ${ }^{29}$

Dual infections were considered a possibility in seven of 38 patients. These patients had a diagnostic finding of another microbe in addition to a positive HSV-PCR. Significantly increased levels of antibodies to varicella zoster virus in CSF were found in two patients. Similar findings of dual infection have been reported previously, based on PCR results. ${ }^{30}$ It may therefore be important to do multiple PCR tests on the same specimen. With regard to HSV-1 and HSV-2 dual infections, the separation of closely related bands may be difficult using gel electrophoresis. With microplate detection, ${ }^{29}$ the separation is clearcut and may be confirmed by Southern blotting.

To confirm the use of the HSV-PCR test for clinical diagnostic purposes we have studied a large series of patients with encephalitis. In older age groups, HSV seems the most prevalent cause of encephalitis and with "ideal" timing, the diagnostic hit rate may be $20 \%$ to $35 \%$. In young adults, HSV is a rare cause of encephalitis. The specificity of the HSV-PCR test seemed good in the present study although a "gold standard" reference test is not available in encephalitis cases in general. The PCR test will improve knowledge on viral encephalitis and help to monitor the efficacy of treatment. In the early phase of a CNS disease, PCR is a rapid and sensitive method. At follow up, antibody tests may support the result and possibly establish more diagnoses. The two methods, PCR and antibody determinations, are complementary and should be performed in parallel in clinical laboratory diagnosis. We are grateful to Drs Paul E Klapper and Graham M Cleator,
Division of Virology, Department of Pathological Sciences, Division of Virology, Department of Pathological Sciences, valuable corrections during the manuscript preparation. MK valuable corrections during the manuscript preparation. MK,
PEK, and GMC are members of the European Union on PEK, and GMC are members of the European Union on Concerted Action on Virus Meningitis and Encephalitis. This
study was supported in part by The Sigrid Jusélius Foundation, Helsinki.

Members of the study group are as follows: Seppo Mannila and Kari Uotila, Central Hospital of Kanta-Häme Hämeenlinna; Merja Koivu and Kirsi Mustonen, Centra Hospital of North Karelia, Joensuu; Matti Junes, Marja-Leen Keränen, and Marjo-Riitta Aine, Central Hospital of Lapland, Rovaniemi; Dag Nyman, Åland Central Hospital, Mariehamn Bjarne Udd and Roger Byring, Vaasa Central Hospital, Vaasa; Jussi Valpas and Raili Saari, Central Hospital of South Karelia Lappeenranta; Jaakko Taalas and Anja Selonen, Mikkel Central Hospital, Mikkeli; Vilho Myllylä and Heikki Rantala Oulu University Hospital, Oulu; Hannu Kilpeläinen and Juhan Sankala, Savonlinna Central Hospital, Savonlinna; Ar Saarinen, Kajaani Central Hospital, Kajaani; Keijo Koivisto Juho Nuutinen, and Matti Korppi, Kuopio University Hospital Kuopio; Markus Färkkilä and Ville Valtonen, Helsink University Hospital, Helsinki; Marketta Muttilainen and Kar Aho, Jorvi Hospital, Espoo; Jussi Kovanen, Koskela Hospital, Helsinki; Christine Hedman and Ritva Norja, Central Hospital of Päijät-Häme; Maija Rummukainen, Central Hospital of Centra Finland, Jyväskylä; Marjaana Luisto and Eero Kaprio, Peijas Rekola Hospital, Vantaa; Antero Pilke and Raili Riikonen Central Hospital of Kymenlaakso, Kotka; Seppo Tuisku and Markus Väre, Central Hospital of Central Pohjanmaa, Kokkola Jukka Porras, Regional Hospital of Lohja Area, Lohja; Vinet Jukka Porras, Regional Hospital of Lohja Area, Lohja; Vineta Fellman and Pentti Ukkonen, Children's Hospital, Helsink Anna-Liisa Järvenpää, Midwife College Hospital, Helsink Juhani Lähdevirta and Eeva Salo, Aurora Hospital, Helsink Hannele Havanka and Liisa Herva, Central Hospital of LänsiPohja, Kemi.

1 Powell KF, Anderson NE, Frith RW, Croxon MC. Noninvasive diagnosis of herpes simplex encephalitis. Lance 1990;335:357-8.

2 Rowley AH, Whitley RJ, Lakeman FD, Wolinsky SM Rapid detection of herpes simplex virus DNA in cerebrospinal fluid of patients with herpes simplex encephalitis. Lancet 1990;335:440-1.

3 Lakeman FD, Whitley RJ, and the National Institute of Allergy and Infectious Diseases Collaborative Antiviral Study Group. Diagnosis of herpes simplex encephalitis: application of polymerase chain reaction to cerebrospinal fluid from brain-biopsied patients and correlation with disease. F Infect Dis 1995;171:857-63.

4 Millner M. Komplizierter Fieberkrampf versus HerpesEncephalitis. Padiatr Padol 1993;28:A7-9.

5 Cohen BA, Rowley AH, Long CM. HSV type 2 in a patient with Mollaret's meningitis: Demonstration by polywith Mollaret's meningitis: Demonstration by

6 Tyler KL. Polymerase chain reaction and the diagnosis of viral central nervous system diseases. Editorial. Ann Neurol 1994;36:809-11.

7 DeVincenzo JP, Thorne G. Mild herpes simplex encephalitis diagnosed by polymerase chain reaction: a case repor and review. Pediatr Infect Dis $\mathcal{F}$ 1994;13:662-4

8 Ando Y, Kimura H, Miwata $H$, Kudo T, Shibata $M$, Morishima T. Quantitative analysis of herpes simplex virus DNA in cerebrospinal fluid of children with herpes simplex encephalitis. F Med Virol 1993;41:170-3.

9 Legido A, Miles DK, Foley CM, et al. Relapse of herpes 
simplex encephalitis after adequate acyclovir therapy [abstract]. Ann Neurol 1994;34:535.

10 Piiparinen H, Vaheri A. Genotyping of herpes simplex viruses by polymerase chain reaction. Arch Virol 1991; 119:275-83.

11 Kwok S, Higuch R. Avoiding false positive with PCR. Nature 1989;339:237-8.

12 Koskiniemi $M$, Piiparinen $H$, Leikola $M$, Färkkilä $M$, Vaheri A, and the Study Group. Poor antibody production in fatal herpes encephalitis. F Infect Dis 1991;171: 1692-3.

13 Levine DP, Lauter CB, Lerner AM. Simultaneous serum and CSF antibodies in herpes simplex virus encephalitis. $\mathfrak{f A M A} 1978 ; 240: 356-60$.

14 Julkunen I. Serological diagnosis of parainfluenza virus infections by EIA with special emphasis on purity of viral infections by EIA with special emphasis

15 Wang S-P, Grayston JT. Immunologic relationship between genital tric, lymphogranuloma venereum, and related organisms in a new microtiter indirect immunofluorescence test. Am F Ophthalmol 1970;70:367-74.

16 Wahlberg P, Saikku P, Brummer-Korvenkontio M. Tickborne viral encephalitis in Finland. The clinical features of Kumlinge disease during 1959-1987. F Intern Med 1989;225:173-7.

17 Hedman K, Vaheri A, Brummer-Korvenkontio M. Rapid diagnosis of hantavirus disease with an IgG-avidity assay. Lancet 1991;338:1353-6.

18 Aurelius E, Johansson B, Sköldenberg B, Forsgren M Encephalitis in immunocompetent patients due to HSV type 1 or 2 as determined by type-specific polymerase type 1 or 2 as determined by type-specific polymerase
chain reaction and antibody assays of CSF. $₹$ Med Virol chain reaction and

19 Nahmias AJ, Whitley RJ, Visintine AN, Takei Y, Alford CA $\mathrm{Jr}$, and the Collaborative Antiviral Study Group. HSV encephalitis: laboratory evaluations and their diagnostic significance. F Infect Dis 1982;145:829-36.

20 Anderson NE, Powell KF, Croxon MC. A polymerase chain reaction assay of cerebrospinal fluid in patients with suspected herpes simplex encephalitis. $f$ Neuro
Neurosurg Psychiatry 1993;56:520-5.

21 Whitley RJ. Herpes simplex viruses. In Fields BN, Knipe DM, eds. Virology. New York: Raven Press, 1990: 1843-88.

22 Klapper PE, Cleator GM, Tan SV, et al. Diagnosis of herpes simplex encephalitis with PCR. Lancet 1993;341:691.

23 Kimura $\mathrm{H}$, Futamura $\mathrm{M}$, Kito $\mathrm{H}$, et al. Detection of viral DNA in neonatal herpes simplex virus infections: Frequent and prolonged presence in serum and cerebrospinal fluid. F Infect Dis 1991;164:289-93.

24 Puchhammer-Stöckl E, Heinz FX, Kundi M, et al. Evaluation of the polymerase chain reaction for diagnosis
of herpes simplex virus encephalitis. $\mathcal{f}$ Clin Microbiol of herpes simp

25 Liedtke W, Opalka B, Zimmermann CW, Lignitz E. Age distribution of latent herpes simplex virus 1 and varicellazoster virus genome in human nervous tissue. 7 Neurol Sci 1993;116:6-11.

26 Uren EC, Johnson PDR, Montanaro J, Gilbert GL. Herpes simplex virus encephalitis in pediatrics: diagnosis by detection of antibodies and DNA in cerebrospinal fluid. Pediatr Infect Dis $\mathcal{F}$ 1993;12:1001-7.

27 Highlander SL, Dorney DJ, Gage PJ, et al. Identification of mar mutations in herpes simplex virus type 1 glycoprotein B which alter antigenic structure and function in virus penetration. 7 Virol 1989;63:730-8.

28 Chou J, Kern ER, Whitley RJ, Roizman B. Mapping of HSV1 neurovirulence to gamma 34.5 , a gene nonessential for growth in culture. Science 1990;250:1262-6.

29 Vesanen M, Piiparinen H, Kallio A, Vaheri A. Detection of herpes simplex virus DNA in cerebrospinal fluid samples using polymerase chain reaction and microplate using polymerase chain reaction and

30 Casas I, Tenorio A, deOry P, Lozano A, Echevarria JM. Dual detection of $\mathrm{HSV}$ and VZV-specific DNA sequences in CSF samples from immunocompetent patients with acute neurological disease. In: Progress in clinical virology. 1994 joint meeting of European Group Rapid Viral Diagnosis Society Against Virus Diseases. Stockholm, Sweden, 14-18 August 1994, p P5/18. 